\title{
Author Correction: c-Met activation leads to the establishment of a TGF $\beta$-receptor regulatory network in bladder cancer progression
}

Wen Jing Sim, Prasanna Vasudevan lyengar (1), Dilraj Lama, Sarah Kit Leng Lui, Hsien Chun Ng,

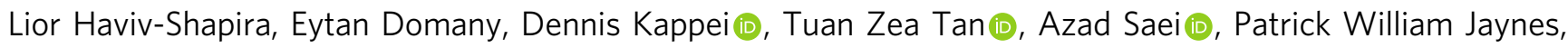
Chandra Shekhar Verma, Alan Prem Kumar (1), Mathieu Rouanne, Hong Koo Ha, Camelia Radulescu, Peter ten Dijke, Pieter Johan Adam Eichhorn (1) \& Jean Paul Thiery (D)

Correction to: Nature Communications https:/doi.org/10.1038/s41467-019-12241-2, published online 25 September 2019.

The original version of this Article contained an error in the spelling of the author Azad Saei, which was incorrectly given as Azad Saie. This has now been corrected in both the PDF and HTML versions of the Article.

Published online: 08 November 2019

\footnotetext{
(c) Open Access This article is licensed under a Creative Commons Attribution 4.0 International License, which permits use, sharing, adaptation, distribution and reproduction in any medium or format, as long as you give appropriate credit to the original author(s) and the source, provide a link to the Creative Commons license, and indicate if changes were made. The images or other third party material in this article are included in the article's Creative Commons license, unless indicated otherwise in a credit line to the material. If material is not included in the article's Creative Commons license and your intended use is not permitted by statutory regulation or exceeds the permitted use, you will need to obtain permission directly from the copyright holder. To view a copy of this license, visit http://creativecommons.org/licenses/by/4.0/.
}

(C) The Author(s) 2019 